Chapter Four

\title{
Beyond the Spitfire: Re-visioning Latinas in Sylvia Morales' A Crushing Love
} (2009)

Catherine Leen

From Dolores del Río to Salma Hayek and from Lupe Vélez to Eva Longoria, the portrayal of Latinas in the United States has provoked debate, criticism and controversy. Since the era of silent movies, Hollywood's depiction of the Latina has been rigidly prescribed and reductive, while Latinos and Latinas themselves have contested these problematic portrayals in more nuanced and multifaceted visions of their communities. Sylvia Morales's documentary A Crushing Love: Chicanas, Motherhood and Activism (2009) presents a vision of activists and mothers that is radically at odds with the stereotypes of Latinas in Hollywood film and in the US media more generally. ${ }^{1}$ This chapter examines the film against the context of persistently problematic representation of Latinas in the media and the ways in which Morales' film counters demeaning images of Chicanas through a multilayered examination of different experiences of motherhood by politically radical women.

\section{Twenty-first century foxes: Latinas on and behind the screen}

The well known sexualised images of Latinas in mainstream US media are perhaps most troubling because of their endurance and the paucity of other images to counterbalance them. As recently as 1995, Chicana theorist and writer Ana Castillo noted that: 'We almost never see women reflective of ourselves (except usually in stereotypes) on television, in Hollywood productions, popular U.S. literature, or anywhere in mass media' (Castillo 1995: 191). Latinas have been relegated to an extremely limited range of roles that overwhelmingly present them as exotic, erotic others whose excessive sexuality is matched only by their irascible and irrational temperaments. The other typical representations of Latinas, which may also include elements of the prevalent 
highly sexualised characterisation, are as criminals or maids. Films such as Edward James Olmos' American Me (1992) and Allison Anders' Mi vida loca/My Crazy Life (1993) depict Chicanas as gang members, while a multitude of films, such as Amy Heckerling's Clueless (1995), James L. Brooks' Spanglish (2004) and Alejandro González Iñárritu's Babel (2006), portray Latinas as maids. In Wayne Wang's Maid in Manhattan (2002), Jennifer López's character combines all three stereotypes of the Latina - despite being sacked from her job as a maid for stealing, her allure is such that she wins the heart of a rich white man. As Ana M. López reminds us, these persistent images are not merely hackneyed tropes in entertainments that can be dismissed as inaccurate and unrealistic but are indicative of the power of the media to shape beliefs about ethnic groups and their difference:

Hollywood does not represent ethnics and minorities: it creates them and provides an audience with an experience of them. Rather than an investigation of mimetic relationships, then, a critical reading of Hollywood's ethnographic discourse requires the analysis of the historical-political construction of self-'other' relations - the articulation of forms of difference, sexual and ethnic - as an inscription of, among other factors, Hollywood's power as ethnographer, creator and translator of 'otherness'. (López 1993: 68)

The fortunes of two stars of the silent era whose careers survived the advent of sound are indicative of the power of Hollywood to shape perceptions of the Latina as other. Joanne Hershfield, in her study of the career and screen image of Dolores del Río, comments that the early years of Hollywood saw what she terms 'racial cross dressing', whereby white actors represented various ethnicities, Asian actors could be cast as American Indians and Mexicans could play 'half-breed Indians and Polynesian princesses' (Hershfield 2000: 3). As del Río herself noted, however, within this racialised casting only light-skinned actors could play any nationality, and she herself was often described as Spanish, to the point where she yearned to play the role of a Mexican woman that would reflect the richness of her culture (Rodríguez 2004: 61). She managed to do so only after returning to Mexico and starring in numerous acclaimed films, including Emilio Fernández's María Candelaria (1943) and Flor silvestre/Wild Flower (1944) (Mora 2005: 61). Her compatriot and contemporary Lupe Vélez was, on 
the other hand, unambiguously portrayed as Mexican and thus relegated to roles as 'the vamp, the wildcat, the vixen' (Rodríguez 2004: 69). Known as the 'Mexican Spitfire' in reference to a series of films of the same name, very little differentiation was made between her on-screen roles and her off-screen life in magazines, newspapers, interviews and other publicity materials. As a consequence, she did not enjoy the same freedom as del Río to reinvent her persona and her enduring image remains that of the tempestuous Mexican troublemaker (Rodríquez-Estrada 1997: 475-93).

Over eight decades later, Latinas in Hollywood today are subject to the same relentless stereotyping and typecasting as del Río and Vélez, although they have taken on roles behind the screen that seem to offer some hope that this scenario may change. In a pattern that reverses del Río's move from achieving stardom in Hollywood and returning to Mexico to play a decisive role in its nascent film industry, Salma Hayek had a very successful career in Mexico, first as a soap opera star and then in serious dramatic roles in films such as Jorge Fons' El callejón de los milagros/The Street of Miracles (1995). This success in Mexico did not ease her way to Hollywood stardom, however, and she was initially cast in very small parts, such as a minor supporting role in Mi vida loca (Rodríguez 2004: 217). Her roles in mainstream films such as Barry Sonenfeld's Wild Wild West (1999) have centred on her erotic exoticism, much in the same way as Vélez's did. She has starred in less mainstream films, however, such as Kevin Smith's Dogma (1999), and established her own production company, Ventanarosa, which has produced films such as In the Time of the Butterflies (2001), an adaptation of Dominican author Julia Alvarez's novel about feminist revolutionaries (Molina Guzmán 2007: 122). Her collaboration on the biopic Frida (2002), about the iconic Mexican artist, best illustrates the ways in which the Latina body in Hollywood continues to be a contested site. The Frida Kahlo film was celebrated by some critics, such as Carl J. Mora, who commended it for bringing a Mexican story to Hollywood and showcasing the acting and producing talents of a Mexican woman (Mora 2005: 187). Criticisms of the film abounded, however, some of which took objection to the fact that the decision to have the characters speak English was inauthentic. There were also many concerns that Kahlo's significance as an artist and a political figure was elided in a character that was as relentlessly sexualised as the traditional Latina screen vamp. ${ }^{2}$ 
More recently, Eva Longoria's foray into producing the Desperate Housewives spinoff Devious Maids has also been roundly criticised, both for the sexualised portrayal of the lead characters and the fact that all four of the female protagonists play domestic servants. Longoria had herself played a stereotypically vampish character in Desperate Housewives and received negative coverage for this (Merskin 2007). It might have been expected, therefore, that she would distance herself from such a role when she came to produce her own show. Longoria did, but instead resurrected the other most common stereotype about Latinas - that they work only as domestic servants. Devious Maids centres on the attempts of four Latina maids to discover the truth about the murder of their friend Flora Hernández, who was working as a maid in Beverly Hills at the time of her death. Even the protagonist, who is not a maid but a college professor - Marisol Suárez, played by Ana Ortiz - prefers to pose as a maid, for reasons that remain obscure, than to take the obvious step of hiring a professional detective to solve the crime. When the killer is found, Marisol does not return to academia but instead marries a wealthy man in Season 2 and sets up a maid service business in Season 3. While again the reasons for this change of career are never given, it may well reflect the fact that Latinas are perceived to be believable on-screen only if they play maids or trophy housewives like Longoria's character in Desperate Housewives. This plot development could, in the absence of any explanations for it in the series, be seen either as stereotypical or as subtly subversive, as Marisol, despite seeming to revert to type, is an independent, resourceful character who remains true to her Latina heritage despite her privileged position in society.

The misgivings about the work of Hayek and Longoria in depicting Latinas as either sirens or maids are well founded, but they also speak to the dearth of representations of Latinas in Hollywood and the intense pressure brought to bear on Latinas who act as producers and directors. Morales considers the criticism of Longoria's show excessive, and points out that Latino directors are not subject to the same censure for using stereotypes in their work. While Morales acknowledges that the series' presentation of Latinas working as maids as an entertaining plot is problematic, she considers it to be a starting point: 'I think we need to set the bar high but not crush anything that's coming up that we feel is not political enough. Eva [...] is trying to do something. She's in there, so she could start an infrastructure' (Morales 2014). Morales 
also contrasts the response to Longoria's series with the reception of the work of Chicano director Robert Rodriguez:

Let's look at Robert Rodriguez. Have you seen his movies? They're not political [...] he's not being critiqued but Eva is. There's a double standard. [...] he had a big success with [...] El mariachi. To me, it was well done but it was very stereotypical - the man saves the woman who was raped and he's going to kill everybody. [...] it was very accepted because it's the normative -man saves woman, protects and will kill for her but she's got to die in order for him to be a man, and I don't like those movies - but he was not put down for it because that's the normative. We don't like the normative of the maids, I understand that, but it's still a double standard. (Morales 2014)

It is also worth noting that Rodriguez directed Hayek in a number of stereotypically sexualised roles in films such as Desperado (1995) and From Dusk Till Dawn (1996). ${ }^{3}$ In the latter film, Hayek plays Santanico Pandemonium, a dancer in a Mexican bar called the Titty Twister. Amid raucous rock music and a myriad of topless or bikini-clad dancers, she appears on-stage in a feathered headdress, miniscule bikini and a flowing red cloak. The cloak is cast off to reveal an enormous snake, which slithers around her body as she begins a sensual dance. Her performance is constantly intercut with shots of the male spectators' lascivious gaze. She leaves the stage and sashays across the bar's tables to face audience member Richard Gecko (Quentin Tarantino), who pours whisky down her leg and then drinks it from her outstretched foot. As a violent brawl erupts, she remains motionless until, at the sight of the blood dripping from Gecko's injured hand, she transforms into a lizard-headed vampire. This disturbing transformation prompts all of the Mexicans in the bar to turn into vampires, with the women leading an orgy of macabre attacks on men. Film critic Charles Ramírez Berg asked Rodriguez to address criticisms of Hayek's role, pointing out that the portrayal of the Mexican women in the film as vampires was problematic and could be conflated with the traditional one of Mexican women as vamps. Rodriguez first holds Tarantino's script responsible for the role, but then argues that the roots of the character lay in Aztec mythology:

I based Salma's character (Santanico Pandemonium) on a figure out of Aztec mythology, a goddess with a skull head and snakes. There was a vampire cult 
that believed that they had to kill to keep the sun shining. We found, you could say, vampires in Mexican history with this cult. [...] I added the snake dance because the image of that goddess was full of snakes and she was the queen of that cult. (Ramírez Berg 2002: 250)

Rodriguez cites Aztec mythology here in a decidedly self-interested manner that recalls Cherrie Moraga's indictment of the leaders of the male-dominated 1970s Chicano Movement for using 'a kind of "selective memory," drawing exclusively from those aspects of Mexican and Native cultures that served the interests of male heterosexuals' (Moraga 2009: 230). Rodriguez justifies his presentation of Hayek's character in an intensely sexual and violent manner by linking it to the figure of the goddess Coatlicue, who is recognisable in his account only from the reference to the skull. He refers to this goddess in an attempt to make Hayek's character more complex and culturally embedded but refuses to engage with the complexity of Coatlicue, who, as Gloria Anzaldúa explains, is a contradictory and multifaceted deity:

In her figure, all the symbols important to the religion and philosophy of the Aztecs are integrated. Like Medusa, the Gorgon, she is a symbol of the fusion of opposites: the eagle and serpent, heaven and the underworld, life and death, mobility and immobility, beauty and horror. (Anzaldúa 2007: 69)

Far from being criticised for presenting Latinos and Latinas in a stereotypical manner, Rodriguez has been commended by Frederick Luis Aldama for using Latinidad 'in ways that playfully foreground or overturn the stereotypes', with no reference whatsoever to gender politics (Aldama 2015: 5). Later in the same volume, there is some discussion of possible sexism in From Dusk Till Dawn, although this is explained in terms of the film's genre and contextualised with regard to Rodriguez's work as a whole (Aldama 2015: 197-225). Elsewhere, Aldama interprets Hayek's hyper-sexualised role in the film as 'carnivalesque' (2015: 59). Latinas, on the other hand, as we see from the critiques of Longoria and other Latinas, are offered no such latitude. Their representations of women in fictional, comedic series are taken as seriously as any documentary and given no credit for the inventiveness or playfulness credited to Rodriguez. 
A case in point is an article from the New York Times that criticised both Longoria's Devious Maids and the comedy series Modern Family, which stars Colombian actress Sofia Vergara as a sexy trophy wife, and that noted that both series failed to appeal to Latina/o viewers. The article cited Mexican-American documentary filmmaker Liz Colunga, who lamented the theme of Devious Maids as stereotypical and saw Vergara's role as 'the clueless Latina' (Vega and Carter 2012). Colunga's reservations are understandable, yet the burden of responsibility is placed squarely on Latinas here, while, as we have seen, Latinos have also presented Latinas in stereotypical ways in their work without attracting negative comment. Moreover, Devious Maids, despite its less than revolutionary form, does weave some social critique into its melodramatic narrative. In Episode 1 of Season 3, for instance, protagonist Marisol Suárez attends a party to celebrate the publication of her book Coming Clean: My Year Undercover as a Beverly Hills Maid. She soon leaves in disgust, however, having upbraided a group of wealthy Anglo housewives for their condemnations of their maids as lazy, stupid and thieving. Vergara's character in Modern Family, meanwhile, is much more complex than the stereotype of the sexy siren - she is a savvy, witty woman who supported her son Manny by working as a hair stylist by day and a taxi driver by night before meeting her wealthy husband. A more recent example of a mainstream show that subverts the stereotypes of Latinas from within the confines of the soap opera genre is Jane the Virgin. This series follows the eponymous virgin protagonist as she attempts to deal with an unexpected pregnancy, which occurred when a distracted doctor mistakenly artificially inseminated her instead of another patient. The show's conflation of IVF with the Immaculate Conception is a provocative concept that challenges the neat categories into which screen Latinas are relegated. Younger Latinas may well look more to Gina Rodríguez, the star of Jane the Virgin, and América Ferrera, who played the titular role in Ugly Betty, as role models rather than the previous generation represented by Hayek or Longoria. Rodríguez and Ferrera have yet to take on roles outside acting, however, so that although their projects and representations of Latinas may be flawed, the work of Hayek and Longoria remains an important advance in selfrepresentation that mirrors the lesser-known work of Chicana producers and directors such as Sylvia Morales, as we shall see in the next section. 


\section{Latinas, feminism and motherhood}

Chicana theorists, writers and artists have had a varied and complex relationship with what they often term mainstream or white feminism. As well as confronting gender oppression and sexism, Chicanas have had to overcome racial prejudice and difficulties related to their often straitened circumstances. In her foundational text Borderlands/ $L a$ Frontera: The New Mestiza, Anzaldúa outlines the challenges facing Chicanas who, through education, can aspire to roles other than nun, prostitute or mother. She cautions that this is an option open to very few Chicanas because of financial constraints, however, and that 'educated or not, the onus is still on woman to be a wife/mother' (Anzaldúa 2007: 39). The Chicano Movement, which did much to address the class and racial oppression endured by Mexican Americans, has been widely criticised for considering the issue of gender to be unimportant or even a potential threat to its goals:

The Chicano Movement built a group identity for the Mexican American working class in the 1960s that derived its impetus from antiracist politics and from a recuperation of cultural traditions based on an ethos of group solidarity and cultural distinctiveness. This ethos appealed to 'tradition' for culturally specific images of solidarity, such as the family or carnalismo, both of which, in the vision offered by male activists (and often agreed to by women), reproduced gender hierarchies and heterosexual identities. For Chicanas who had begun to move away from 'tradition,' or at least had been engaged in a process of transformation, this vision stood in contrast to the complexities of family life in the barrio and U.S. society. (Espinoza 2003: 99)

As the above comment suggests, the Chicano Movement was not only divided along gender lines but women responded in various ways to the challenges that faced them. Citing Anna NietoGomez and other Chicana scholars, Maylei Blackwell makes the important observation that there was a marked difference between "Feministas" and those movement women who, although they were "strong women" and good organisers, were "Loyalists" to the nationalist party line' (2003: 77). Despite attempts to relegate them to secondary roles in the Movement and even opposition from some 
women to the unmasking of such conflicts within Chicana/o culture, Chicanas spoke out strongly against gender oppression. Writers such as Cherrie Moraga have written extensively on the problematic nature of the rigidly gendered roles traditionally ascribed to both men and women. Noting the refusal to acknowledge the divisions and problems within Chicana/o families, she suggests that until such issues are addressed there can be no unity on a wider scale and so true solidarity remains elusive:

We believe the more severely we protect the sex roles within the family, the stronger we will be as a unit in opposition to the Anglo threat. And yet, our refusal to examine all the roots of the lovelessness in our families is our weakest link and softest spot. Our resistance as a people to looking at the relationships within our families - between husband and wife, lovers, sister and brother, father, son, and daughter, etc. - leads me to believe that the Chicano male does not hold fast to the family unit merely to safeguard it from the death-dealings of the Anglo. Living under Capitalist Patriarchy, what is true for 'the man' in terms of misogyny is, to a great extent, true for the Chicano. (Moraga 1983: 110)

In response to the lack of support and understanding from many in their community, Chicanas organised to create spaces in which they could produce creative work. Anzaldúa, Moraga and other writers and theorists such as Norma Alarcón were at the forefront of a generation of women whose poetry, essays and fiction gave voice to the experiences of Chicanas in the 1970s and 1980s. Ellen McCracken reminds us, in her account of the continuing importance of this early work to contemporary Chicana writers, that Chicanas even founded their own printing presses and journals in order to publish the work of women writers, who were often dismissed as less political than their male peers (2014: 11-15). Latina and Chicana writers, therefore, redefined community 'as a sisterhood and non-familial solidarity' within which mothering became 'a form of pedagogy, inside and outside the home' (Santos and Crowe Morey 2013: 90). One way in which Chicanas formed their own canon was to collaborate with other women of colour to produce groundbreaking collections of feminist writing such as This Bridge Called My Back (1984) edited by Anzaldúa and Moraga, and Making Face, Making Soul: Creative and Critical 
Perspectives by Feminists of Color (1990), edited by Anzaldúa. Such projects were not always straightforward, however. Moraga has noted that in producing the former volume she was disappointed to discover that women of colour could be homophobic and that she encountered 'racism among us crossculturally' (Saldívar-Hull 2000: 51).

Another strategy that would seem to offer some respite from the chasm between men and women in the Chicano Movement was working with white feminists. Ana Castillo, who coined the term Xicanista to describe an identity 'not just Chicana, not activista for La raza, not only a feminist but a Chicana feminist', has written that many Chicanas could not relate to the white women's movement, which, in turn, did not recognise them (1995: 94-5). Teresa Córdova sums up the situation of Chicanas who experienced gender discrimination from their male activist peers in the Movement, yet could not embrace mainstream feminism:

Chicanas write in opposition to the symbolic representations of the Chicano movement that did not include them. Chicanas write in opposition to a hegemonic feminist discourse that places gender as a variable separate from that of race and class. Chicanas write in opposition to academics, whether mainstream or postmodern, who have never fully recognised them as subjects, as active agents. (Córdova 2003: 1)

In her account of the development of Chicana Studies, Edén E. Torres goes further, asserting that there is clear racism in the valuation of the work of US or French feminist theorists as superior to that of female Native American, Latina or African American scholars. She adds that the assumption that all college students should be familiar with these theories is in itself a reflection of 'a Eurocentric bias as it presumes everyone should or would want to understand the world through these particular lenses' (Torres 2003: 65). Another factor that played a role for many Chicanas in their development of a unique identity was religion or spirituality. While Moraga describes herself as Marxist though constantly engaging with her preColumbian heritage, Castillo suggests that Marxist theories about the oppression of working-class people are incompatible with Chicana spirituality, a view espoused also by Anzaldúa. ${ }^{4} \mathrm{~A}$ final obstacle to Chicanas' embracing of white feminism was the conflation of the term with lesbianism by traditionalists within Chicana/o culture, as Gaspar de Alba signals: 
One of the accusations launched at the feministas, apart from calling them agringadas, Malinches, and FBI spies, was the term lesbian. Because they were believed to be anti-familia, they could be nothing but lesbians, according to the machista logic, and the term lesbians, of course, was a bad word, a dirty name. (Gaspar de Alba 2014: 74)

This is not to say that all Chicanas rejected mainstream feminism out of hand. Moraga has commented on the irony that Chicano theorists cite Marx and Engels without fear of criticism, while the referencing of the work of white feminists by Chicana feminists is seen to be problematic (1983: 106). Gaspar de Alba, meanwhile, references mainstream feminist theory in her work while reminding us that there have been many Latina precursors to Chicana feminism, including Sor Juana Inés de la Cruz (Gaspar de Alba 2014).

All of this brings us back to the issue of motherhood. If there are few works by Chicana theorists that deal directly with motherhood, there is an abundance of work, both textual and visual, about the key figure of the Virgen de Guadalupe. The Virgen de Guadalupe is revered both by men and women in the Chicano Movement as a symbol of solidarity and as the patron of the poor and oppressed. While this veneration, like that of the worship of other virgins in Catholic iconography, has been interpreted by women in contemporary society as repressive and presenting an impossible ideal that women cannot emulate, Chicana writers and activists have reimagined the figure of the Virgen as a modern, feminist and sometimes queer icon. In an essay published in $M s$ entitled 'Guadalupe the sex goddess', Sandra Cisneros relates the virgin to pre-Columbian goddesses such as Coatlicue and reflects on her importance to the sexual development of Latinas (1996: 43-6). So many Chicana artists have reinterpreted her figure in their work that it has become a distinct genre, which has been analysed by Gaspar de Alba and artist Alma López in their volume Our Lady of Controversy (Gaspar de Alba and López 2011). While these reinterpretations of the Virgin are extremely diverse, they share a vision of her as a symbol of solidarity and empowerment, rather than oppressive patriarchy. Just as the figure of the Virgin is multivalent and even ambivalent, so too the representation of motherhood in cinema is something of a contested site for Chicanas, as we shall discuss in the following section. 


\section{Motherhood in Chicana/o films: from mamís to mamás}

If the preponderance of Hollywood images of Latinas remains mired in the stereotype of the sexy seductress, alternative visions of women in films made by Chicano filmmakers often fall into the trap of desexualising women entirely. No other cinematic trope could accomplish this as completely as the Latina mother. In spite of the efforts by women to carve a space for themselves within the Chicano Movement, as we have seen, its malecentred politics was undoubtedly reflected in the early years of Chicana/o filmmaking. The first Chicano film, Luis Valdez's I Am Joaquin (1969), which I will return to when discussing the career of Sylvia Morales, represented Chicano history almost entirely from the point of view of men. Mothers and, predictably, the traditional image of the Virgen de Guadalupe, were the only women featured. Moreover, the four Chicano films made in the late 1980s that led to media speculation about a 'Hispanic Hollywood' - La Bamba (1987), Born in East L.A. (1987), Stand and Deliver (1988) and The Milagro Beanfield War (1988) - were all directed by men and focused on male protagonists (Goldman 1987: 82). While these films are laudable for their exposure of the myriad ways in which institutionalised racism affected the lives of Latinos in areas as diverse as socio-economic mobility, citizenship, land and education, they are notably lacking in central roles for women, other than as mothers who are important only in relation to their sons or husbands (Fregoso 1993: 130-47).

Even Chicano films that granted women larger roles in their narratives tended to portray women as paragons of self-sacrificing motherhood. In Gregory Nava's El norte (1983), the matriarch of the Xuncax family rarely leaves the kitchen and is remembered fondly by her daughter for her cooking. In Nava's My Family (1995), Jennifer López, in her first major screen role, plays the self-sacrificing matriarch María in a multigenerational saga about a Chicano family. María is entirely defined as the interlocutor between her husband and sons throughout the film, so that, despite her central role, 'the absence of her narrative agency reinforced gender inequality within the family structure as much as it freezes her in time, within the biologically inscribed role of motherhood' (Fregoso 2003: 77-8). The work of Morales and other Latina directors provided much-needed alternatives to this paternalistic, onedimensional view of motherhood. 


\section{A Crushing Love: new visions of motherhood}

In recognition of her contribution to Latina/o film and media, Morales received the Latino Committee Pioneer Award from the Directors Guild of America in 2013. From 1981 to 1985, she led the Latino Consortium at KCET in Los Angeles. She has directed episodes for Showtime's series Resurrection Blvd, PBS's Chicano! The Mexican Civil Rights Movement and the ACE and Emmy-nominated series A Century of Women (Loglines 2013). She is currently a professor at Loyola Marymount University's School of Film and Television in Los Angeles. In her study of Lupe Vélez’s Hollywood career, Carmen Huaco-Nuzum cites Morales as a filmmaker who has reclaimed 'chicana, mestiza, representation from centuries of racial patriarchal containment' (Huaco-Nuzum 1996: 261). Chon A. Noriega also recognises Morales as one of the outstanding female filmmakers whose work was crucial to the development of Chicana/o cinema:

Although Chicanas such as Susan Racho, Sylvia Morales, Esperanza Vasquez, and Lourdes Portillo were instrumental in the first decade of Chicano cinema, their work has not received the same critical attention as male-produced films [...] and yet, it is the Chicana-produced work that has consistently challenged and redirected the cultural paradigms of Chicano cinema. (Noriega 1993: 86)

Her first film, Chicana (1979), has been interpreted as 'the feminist counterpart to the first Chicano film, I Am Joaquín' (Fregoso 1993: 39). Morales observes that she found Valdez's film inspiring, but she was struck by the absence of women in his account of Chicano history and so made her film to reinscribe Chicanas into Mexican-American history (Morales 2014). Throughout her career, Morales has focused on issues of women, family and Chicana feminism (Hidalgo de la Riva 2006: 53). The documentary $A$ Crushing Love pays tribute to five ground-breaking Chicana activists, all of whom are mothers who have redefined the roles of Chicanas in society. Morales' examination of the achievements of these women is interwoven with scenes of her own struggle to make the film while looking after her teenage daughter, Michelle. Her exploration of the different ways in which her subjects reconcile motherhood with their work challenges the stereotypical and reductive representations of Latinas in the mainstream media, and 
stands in sharp contrast to the way in which Latina mothers have been portrayed in Latino films.

The film begins in medias res, with Morales editing her film at home as Michelle asks her to make her something to eat (see Figure 4.1). As an interview with United Farm Workers' co-founder Dolores Huerta plays in the background, Morales insists that she is busy and that Michelle should make herself something to eat. Michelle responds in a rather sulky manner, leaving Morales distracted and under pressure to return to work.

Figure 4.1: Michelle interrupts Sylvia editing the documentary A Crushing Love

This mother-daughter argument, interspersed with an interview with Huerta, sets the scene for the film to follow, as Morales' own experience of the frustrations of trying to make her film while caring for her daughter is interwoven with the stories of the Chicana activists she interviews - the aforementioned Huerta; Elizabeth 'Betita' Martínez, educator and author of 500 Years of Chicana History; Alicia Escalante, Civil Rights activist and founder and director of the East LA Welfare Rights Organization; Martha Cotera, entrepreneur and author of Diosa y hembra; and Cherrie Moraga, theorist and writer. The interviews with these pioneering women are combined with archival photographs and footage, inter-titles, interviews with their children, and scenes from Morales' everyday life. Following the establishing sequence, she reflects on her motivations for making A Crushing Love:

I was in the last stretch of completing my documentary on activist women, who grappled with the dual roles of motherhood and justice and social change. As a single mother of two working full time, I wanted to know, how in the world did they do it? [...] When did they find the time to wash and dry the clothes and then fold them? Shop for food, put it away and later cook it? Help the kids with homework and care for them when they were sick. [...] Did they ever find time for themselves? How did they do it all? 
Morales explains that her independent film, which is distributed by Women Make Movies, was initially intended to record the achievements of an older generation of Chicana activists, among them Betita Martínez, who was 84 and had recently had a stroke. While preparing for the interview, Morales discovered, to her surprise, that Martínez had a daughter she had never heard her mention and so she decided to ask her how she combined motherhood and activism (Morales 2014). Martínez's response is characteristically forthright about her shortcomings as a mother:

Looking back then [...] I was so involved in the other work and I thought, well, I'm doing all this work for humanity, and I didn't pay enough attention to the human life that was right in my own hands. I also, you know, I worried about this a lot, and I thought, am I just some kind of weird freak or whatever? I think that it wasn't that I didn't see my daughter as a human being who needed love and attention and everything, but I just didn't define myself as a, quote, mother.

This admission is so contrary to the traditional expectations of Latina mothers and the idealisation of motherhood so prevalent in Latina/o culture that it spurred Morales to organise her documentary around interviews with Chicana activists who are also mothers. Huerta (Figure 4.2), whose interview is juxtaposed with that of Martínez and Huerta's daughter, Alicia, is similarly pragmatic and unsentimental when she discusses childcare arrangements that involved her children living away from her for extended periods:

We really didn't have any full-time babysitters once we started the union, so it made it difficult. [...] But then I had help [...] César's wife, Helen Chávez, two of my kids lived with her. My brother Marshall, who lived up in Oregon, in Washington, a couple of my kids went to live with them for a while. So they kind of shifted around, lived with different people, and then I would take them with me. [...] So they were kind of travelling migrant farmworker movement children, you know. 
Figure 4.2: Dolores Huerta and her children at a meeting of the United Farm Workers

If these interviews are extraordinary in their departure from the expectations of the 'ideal' Latina mother, they are also notable in that a documentary about male activists would never feature such questions. In their study of the Cuban Revolution, Lois M. Smith and Alfred Padula could be referring to the Chicano Movement when they observe that: 'A fundamental problem with male-directed social movements is that their leaders rarely think about who is going to do the dishes' (Smith and Padula 1996: 131). In the same volume, Fidel Castro, in a rare interview where he discusses his family life, appears to congratulate himself for knowing how many children he has: 'Castro himself told a reporter in 1994 that, as far as he knew, he had fewer than a dozen children: “Well, I don't have a tribe," he said' (Smith and Padula 1996: 155). Childcare would not appear to be an issue to which the leader of the Revolution paid much thought. Domestic work and childcare remain the primary concern of women, however, and the revolutionaries in Morales' film constantly juggled these responsibilities in order to achieve social change. If Martínez judges herself harshly as an inadequate mother, Huerta observes that it was her children, rather than herself, who made sacrifices that allowed her to pursue the work she loved.

The influence of their own mothers looms large in the lives of all five of the subjects in different ways - Huerta was inspired by her mother's decision to treat her brothers and herself equally, so that she did not have to serve them or do more chores than they did. Martínez notes that although her mother was Anglo, she was a Spanish teacher and loved Mexico and this helped her to have a strong sense of her identity despite growing up in a predominantly African-American city where she attended an all-white school. Cotera recalls being inspired by her grandmother's and mother's tales of the female soldiers in the Mexican Revolution: 'I swore to myself that I would be the female Pancho Villa'. Cotera and Escalante remark on the profound influence that their mothers' strength in supporting their families as single parents had on their lives. Moraga, meanwhile, speaks of her loneliness at not being able to confide in her mother about her sexuality and her astonishment that her 
'fiercely judgemental' mother was completely supportive of her when she did come out to her.

The interviews with the activists' children also create a powerful testimony of the influence of their mothers on their lives, without glossing over the difficulties that they faced as a result of their mothers' commitment to their work. Alicia Huerta comments movingly on the economic hardship she and her siblings faced because her mother did not take on the typical domestic role of a Chicana mother, but she is unstinting in her praise of her mother's singular achievements: 'She was not the role model or the expectation that they wanted her to be, but now, it took a while for us to recognise, that's a hero, a person that speaks out and cares about others. That's important.' Tess Koning-Martínez, the daughter of Betita Martínez, speaks openly about the pain of feeling, when she was growing up, that her problems were not as important as the global issues that her mother was dealing with. She too reflects on how her mother's unconventional life affected her, but with rather more ambivalence. While she acknowledges that her mother defied expectations of what a Chicana mother should be and thus became an inspiration to Latinas, she has found it difficult to reconcile her expectations of motherhood with her personal experience:

I would say in terms of a not so much stereotypical but archetypal quality about a mother is the idea of the mother dedicating herself to the child and the nurturing of the child and I have struggled with that, because I do feel that that is an important quality of a mother and I don't feel that I've gotten enough or I had my share of that.

Before the film's conclusion, Morales includes the only piece of archival footage that does not depict the women at the heart of her film. This clip depicts a model US family seated beneath a Christmas tree, as the beautifully dressed, softly spoken mother tells her children the story of another ideal and idealised mother, 'a kind young lady, whose name was Mary'. This footage is juxtaposed with an interview with Cotera's daughter, María Eugenia Cotera, who, like Koning-Martínez, addresses stereotypes about motherhood:

Here's what I would call the stereotypical vision of motherhood - it would be like a mother who is so self-sacrificing and so self-abnegating that she loses 
her goals, her dreams, herself in her children, dedicates herself entirely to them, focuses on them, makes their lives as pleasant as possible, something I've talked to other children of activists about. What visions did we hold of childhood and how it should be and how do we feel like we weren't given that? To have a mother that bakes for you, to have a mother that's always there for you in a frilly apron, these are all visions that I don't know of anyone, outside of someone on TV, that has ever experienced that. The thing about stereotypes like that, or these sorts of false visions, is that they make us feel cheated.

Morales' film continues the work of Latina and Chicana feminists in complicating the vision of Latina motherhood. The variety of stories told and the diverse ways in which the activists interviewed reconciled their work with motherhood, to a greater or less degree, re-inscribes a hidden history of feminist activism into Chicana/o history. It also points to how much mothers and their children sacrifice in an attempt to achieve societal change and justice. Morales concludes by drawing her own inspiration from the stories of the other mothers in the film as she works to complete her film: 'I press on with faith, humour and a little grit'.

\section{A Crushing Love: Latina and Latin American activism on screen}

Chon A. Noriega, in his study of early decades of Chicana/o filmmaking, observed that because of the strong connection with Mexico and the contemporary reality of living and working in the United States, Chicana/o filmmakers have had to find a space between Latin America and Hollywood: 'From the start [...] Chicano cinema has had to mark out a space for itself between a weapon and a formula; between the political weapon of New Latin American Cinema and the economic formula of Hollywood' (Noriega 1993: 86). Chicana directors initially produced activist films in the mould of the new Latin American documentary, where the situations portrayed were represented as objective truths barely mediated by their creators. Lourdes Portillo's first film, Las madres: The Mothers of the Plaza de Mayo (1986), is a pan-American exploration of the activism of the Madres de Plaza de Mayo. These mothers, like those in A Crushing Love, were activists who brought about social change through their quest for justice. 
Paradoxically, the Madres de Plaza de Mayo were successful precisely because they organised as mothers, subverting the patriarchal, pro-family rhetoric of repressive military dictatorship in Argentina in the 1970s and 1980s. The Junta initially attempted to discredit their activism by dismissing them as 'las locas de Plaza de Mayo', a term that is recalled by Alicia Huerta's comment that her mother's family thought that her mother, Dolores Huerta, was 'crazy' to move her family to Delano in attempt to improve farm workers' lives. This example underlines the struggle that women face more generally to be taken seriously as activists and organisers in cultures that do not accept that women can be political leaders. The use of extensive interviews with the mothers in Portillo's film, which often deal with memory, has close parallels with A Crushing Love. The memory of the early days of the Chicano Movement looms large in the film, as does the influence of previous generations of women and the recollections of activists' children.

Morales' interweaving of her own story with those of her subjects also makes the film, like Portillo's later documentaries about her own family, intensely personal. Morales did not initially intend to appear in the film herself, as she was wary of seeming to draw comparisons between her work and that of the activists. With much humour, she also comments on how terrible she felt seeing herself appearing less than glamorous. She ultimately decided that the scenes where Michelle films her in unguarded moments added a great deal of levity to the film (Morales 2014). Her decision to include the scenes of her journey towards making the film achieves much more than adding some humour, however, as it opens up a story that may be mistakenly seen as relevant only to Chicana/os to a wider audience interested in the struggles of women to reconcile motherhood with their work, an issue that has been debated since the early days of the women's movement. Morales' personal account of her own motherhood draws the viewer into the story as she and Michelle, who becomes the cinematographer, negotiate boundaries and learn from each other. A powerful unstated message in these scenes is how Michelle, like the children of the activists, continues her mother's legacy. This is turn underlines how Latinas and Chicanas have not only successfully contested the limitations of their culture in their political and creative work but have fashioned their own legacies. Morales' film, to borrow Adrienne Rich's term, re-visions Chicana activism by 'seeing difference differently' and confronting the difficulties of departing from the expectations of motherhood (De Lauretis 2000: 325). 
In so doing, it expands the meanings of motherhood to embrace mentoring, mutual understanding and true solidarity. Morales' film reflects the way in which Chicana filmmakers are creating their own feminist activism, following Anzaldúa's idea of creating a new mestiza consciousness, by integrating their personal stories of the difficulties and rewards of motherhood into Chicana history.

\section{References}

Aldama, Frederick Luis (2015). 'Rodriguez's cinema of possibilities: an introduction', in Frederick Luis Aldama (ed.), Critical Approaches to the Cinema of Robert Rodríguez, Austin: University of Texas Press, pp. 1-14.

Anzaldúa, Gloria (2007). Borderlands/La Frontera: The New Mestiza, San Francisco: Aunt Lute Books.

Blackwell, Maylei (2003). 'Contested histories: Las hijas de Cuauhtémoc', in Gabriella Arredondo, Aida Hurtado, Norma Klahn, Olga Nájera-Ramírez and Patricia Zavella (eds), Chicana Feminisms: A Critical Reader, Durham: Duke University Press, pp. 59-90.

Castillo, Ana (1995). Massacre of the Dreamers: Essays on Xicanisma, New York: Plume. Cisneros, Sandra (1996). 'Guadalupe the sex goddess', Ms, 7/8, pp. 43-6.

Córdova, Teresa (2003). 'Introduction', in Arredondo et al. (eds), Chicana Feminisms: A Critical Reader, pp. 1-18.

De Lauretis, Teresa (2000). 'Rethinking women's cinema: aesthetics and feminist theory', in Robert Stam and Toby Miller (eds), Film and Theory: An Anthology, Malden: Blackwell, pp. 318-36.

Espinoza, Dionne (2003). “"Tanto tiempo disfrutamos...”. Revisiting the gender and sexual politics of Chicana/o youth culture in East Los Angeles in the 1960s', in Alicia Gaspar de Alba (ed.), Velvet Barrios: Popular Culture and Chicana/o Sexualities, New York: Palgrave Macmillan, pp. 89-107.

Fregoso, Rosa Linda (1992). 'Chicana film practices: confronting the "many-headed demon of oppression"', in Chon A. Noriega (ed.), Chicanos and Film: Representation and Resistance, Minneapolis: University of Minnesota Press, pp. 168-82. 
- (1993). The Bronze Screen: Chicana and Chicano Film Culture, Minneapolis: University of Minnesota Press.

- (2003). MeXicana Encounters: The Making of Social Identities on the Borderlands, Berkeley: University of California Press.

Gaspar de Alba, Alicia and Alma López (eds) (2011). Our Lady of Controversy: Alma López's Irreverent Apparition, Austin: University of Texas Press. Gaspar de Alba, Alicia (2014). [Un]framing the "Bad Woman" Sor Juana, Malinche, Coyoloxauhqui and Other Rebels with a Cause, Austin: University of Texas Press.

Goldman, Ilene S. (1996). 'Crossing invisible borders: Ramón Menéndez’s Stand and Deliver (1987)', in Chon A. Noriega and Ana M López (eds), The Ethnic Eye: Latino Media Arts, Minneapolis: University of Minnesota Press, pp. 81-95. Hershfield, Joanne (2000). The Invention of Dolores del Río, Minneapolis: University of Minnesota Press.

Hidalgo de la Riva, Osa (2006). 'Sylvia Morales', Spectator, 26.1, pp. 49-54.

Huaco-Nuzum, Carmen, (1991). '(Re)constructing Chicana, Mestiza representation:

Frances Salomé España’s Spitfire', in Chon A. Noriega and Ana M. López (eds), The Ethnic Eye: Latino Media Arts, Minneapolis: University of Minnesota Press, pp. 260-75.

Loglines (2013). 'Associate Professor Sylvia Morales honored by DGA', 18 October.

Retrieved from http://loglines.lmu.edu/news/associate-professor-sylviamorales-honored-by-dga (accessed 5 June 2015).

López, Ana M. (1993). 'Are all Latins from Manhattan?', in John King, Ana M. López and Manuel Alvarado (eds), Mediating Two Worlds: Cinematic Encounters in the Americas, London: British Film Institute, pp. 67-81.

McCracken, Ellen (2014). 'From chapbooks to Chica lit: U.S. Latina writers and the new literary identity', in Catherine Leen and Niamh Thornton (eds), International Perspectives on Chicana/o Studies: 'This World Is My Place', New York: Routledge, pp. 11-24.

Merskin, Debra (2007). 'Three faces of Eva: perpetuation of the hot-Latina stereotype in Desperate Housewives', Howard Journal of Communications, 18.2, pp. 133-51. 
Molina Guzmán, Isabel (2007). 'Salma Hayek's Frida: transnational Latina bodies in popular culture', in Mayra Mendible (ed.), From Bananas to Buttocks: The Latina Body in Popular Film and Culture, Texas: University of Texas Press, pp. 117-29.

Mora, Carl J. (2005). Mexican Cinema: Reflections of a Society, 1896-2004, North Carolina: McFarland \& Company.

Moraga, Cherrie (1983). Loving in the War Years: Lo que nunca pasó por sus labios, Boston: South End Press.

- (2009). 'Queer Aztlán: the reformation of Chicano tribe', in Francisco Vázques (ed.), Latino/a Thought: Culture, Politics and Society, Maryland: Rowman \& Littlefield, pp. 223-43.

- (2011) A Xicana Code of Changing Consciousness: Writings, 2000-2010, Durham: Duke University Press.

Morales, Sylvia (2014). Interview with the author, Venice Beach, California, 18 July. Noriega, Chon A. (1993). Chicano Cinema: Between a Weapon and a Formula, Chicano Cinema and its Contexts, San Sebastian: Festival Internacional de Cine de Donostia.

Ramírez Berg, Charles (2002). Latino Images in Film: Stereotypes, Subversion and Resistance, Austin: University of Texas Press.

Rodríguez, Clara E. (2004). Heroes, Lovers and Others: The Story of Latinos in Hollywood, New York: Oxford University Press.

Rodríquez-Estrada, Alicia I. (1997). 'Dolores Del Rio and Lupe Velez: images on and off the screen, 1925-1944', in Elizabeth Jameson and Susan Armitage (eds), Writing the Range: Race, Class and Culture in the Women's West, Oklahoma: University of Oklahoma Press, pp. 475-93.

Ruiz-Alfaro, Sofia (2012). 'From Chavela to Frida: loving from the margins', Journal of Homosexuality, 59.8, pp. 1131-44.

Saldívar-Hull, Sonia (2000). Feminism on the Border: Chicana Gender Politics and Literature, Berkeley: University of California Press.

Santos, Cristina, and Crowe Morey, Tracy (2013). '(M)othering the borderlands: testimony and the Latina feminist group', Motherhood in a Global Context, 4.2, pp. 89-105. 
Shaw, Deborah - (2007). 'Robert Rodriguez's Mexicans in Once Upon A Time in Mexico', Reconstruction, 7.3. Retrieved from

http://reconstruction.eserver.org/Issues/074/shaw.shtml (accessed 20

August 2015).

- (2010). 'Transforming the national body: Salma Hayek and Frida', Quarterly Review of Film and Video, 27, pp. 299-313

Smith, Lois M. and Alfred Padula (1996). Sex and Revolution: Women in Socialist Cuba, New York: Oxford University Press.

Torres, Eden E. (2003). Chicana Without Apology/Chicana sin vergüenza: The New Chicana Cultural Studies, New York: Routledge.

Vega, Tanzina and Bill Carter, (2012). 'Networks struggle to appeal to Hispanics without using stereotypes', New York Times. Retrieved from

http://latinocollaborative.com/wp-content/uploads/2012/12/Networks-

Struggle-to-Appeal-to-Hispanics-New-York-Times-Aug-15-2012.pdf (accessed

1 May 2015).

\section{Notes}

\footnotetext{
${ }^{1}$ The term 'Chicana/o' is used throughout this chapter to refer to people of Mexican-American descent in the United States, while the term 'Latina/o,' which will often encompass Chicana/os, is used to refer to people of Latin American descent in the United States. Latino/a is also used in the North American sense, that is, to refer both to Latin Americans, such as the Mexican Salma Hayek, and to people of Latin American descent born in the United States.

${ }^{2}$ See, for instance, Deborah Shaw (2010: 299-313) and Sofia Ruiz-Alfaro (2012: 1131-44).

${ }^{3}$ See also Deborah Shaw's critique of Rodríguez's use of Latina/o stereotypes in Once Upon A Time in Mexico (2007).

${ }^{4}$ See Castillo (1995: 89-92), Moraga (2011) and Anzaldúa (2007).
} 